Tersedia online: http://journal.stainkudus.ac.id/index.php/jbe

\title{
Penerapan Asesmen Written Feedback Untuk Meningkatkan Penguasaan Konsep Siswa SMP
}

\author{
Dyah Ayu Rahma Shiami \\ *) Universitas Muhammadiyah Sukabumi, Jawa Barat Indonesia \\ dyahayurahmasiami@gmail.com
}

\begin{abstract}
ABSTRAK
Penelitian ini berjudul penerapan asessmen written feedback untuk meningkatkan penguasaan konsep siswa. Penelitian ini bertujuan untuk mengeteahui penguasaan konsep siswa melalui penerapan asesmen written feedback dalam pembelajaran materi ekosistem. Metode penelitian yang digunakan dalam penelitian ini adalah metode deskriptif.Sampel pada penelitian ini adalah siswa SMP Negeri 6 Kota Sukabumi kelas VII G dengan jumlah peserta didik 30 orang. Pengambilan sampel penelitian ini diambil secara acak dengan menggunakan teknik purposive sampling. Instrumen yang digunakan dalam penelitian berupa LKS yang digunakan untuk mengukur penguasaan konsep siwa dan lembar angket yang digunakan untuk memperoleh data tambahan berupa respon siswa terhadap pembelajaran dengan penerapan asesmen written feedback . Hasil penelitian menunjukan bahwa pemberian asesmen written feedback dalam pembelajaran dapat meningkatkan penguasaan konsep siswa. Penerapan asesmen written feedback juga dapat mendorong siswa untuk lebih aktif dalam proses pembelajarannya, membangun motivasi siswa untuk mau berproses dan meningkatkan kemampuan yang mereka miliki. Dengan kata lain penerapan asesmen written feedback sangat layak untuk diterapkan dalam pembelajaran disekolah.
\end{abstract}

Kata kunci: Asesmen, Ekosistem, Penguasaan Konsep, Written feedback

\section{ABSTRACT}

This research entitled the application of asessmen written feedback to enhance student mastery. This research aims to mengeteahui the student's mastery of the concepts through the implementation of assessment written feedback in the learning material of the ecosystem. Research methods used in this research is descriptive method. The sample in this research are students of SMP Negeri 6 Sukabumi Class VII G with the number of learners 30 people. Research of sampling was taken at random by using Purposive Sampling technique. The instruments used in the research in the form of Worksheets used to measure students ' mastery of the concepts of Shiva and the question form sheet used to obtain additional data in the form of student response against learning with application assessment written feedback. Results of the study showed that giving written feedback in the learning assessment can improve student mastery. The application of assessment 
written feedback can also encourage students to be more active in the process of the lesson, students motivation to want to build processes and enhance the capabilities they have. In other words, the application of assessment written feedback is very worthy to beapplied in learning in all schools.

Keywords: Assessment, Ecosystem, Mastery of Concepts, Written Feedback

\section{PENDAHULUAN}

Efektifitas pembelajaran dapat tercapai tergantung dari kemampuan guru untuk mencapai keberhasilan proses pembelajaran tersebut. Dalam pembelajaran disekolah, terdapat proses belajar, yaitu proses terjadinya perubahan pengetahuan, sikap, informasi, kemampuan dan keterampilan yang sifatnya permanen melalui pengalaman.

Aspek penting lain dari pelaksanaan pembelajaran yang tidak dapat diabaikan yaitu pelaksanaan penilaian. Dalam Kurikulum Tingkat Satuan Pendidikan dikenal istilah Asesmen Pembelajaran. Bagian penting dari asesmen pembelajaran ini adalah bagaimana cara melakukan penilaian, bagaimana prosedur penilaian, pengolahan data, penetapan skor hingga pelaporannya sehingga gambaran hasil pembelajaran yang dilaksanakan oleh guru selama ini dapat diketahui saja oleh siswa, tetapi juga oleh semua pihak termasuk orangtua dan sekolah (Uno, 2011).

Asesmen merupakan sebuah proses pengumpulan informasi yang terus menerus berlangsung untuk mengukur performansi siswa dan proses pembelajaran. asesmen didefinisikan sebagai proses pengumpulan, pelaporan dan penggunaan informasi tentang hasil belajar siswa yang diperoleh melalui pengukuran untuk menganalisis atau menjelaskan unjuk kerja atau prestasi siswa dan mengerjakan tugas-tugas terkait (Hart 1994).

Berhasil atau tidaknya suatu proses belajar sangat penting untuk diketahui oleh guru, maka dari itu guru perlu melakukan penilaian. Berdasarkan hasil observasi dan wawancara yang telah dilakukan, dewasa ini proses penilaian yang dilakukan oleh guru pada umumnya hanya menekankan pada penilaian hasil belajar yang dilihat dari tes tertulis sebagai alat ukurnya tanpa memperhatikan proses sehingga guru pun tidak mengetahui sejauh mana perkembangan dan pemahaman anak terhadap materi yang disampaikan. Pada umumnya guru-guru kurang mendalami tentang penilaian proses 
belajar. Disamping karena kesibukan, ada kecenderungan guru-guru melaksanakan penilaian apa adanya tanpa memperhatikan proses.

Asesmen written feedback merupakan salah satu asesmen yang dapat digunakan untuk melakukan penilaian selama proses pembelajaran. Beberapa karakteristik dari asesmen written feedback ini diantaranya dapat mengenali dan merespon belajar siswa dalam meningkatkan proses pembelajaran. Dengan demikian tentunya asesmen written feedback dapat memberikan umpan balik selama proses pembelajaran yang akan memantau dan mendorong peningatan penguasaan konsep siswa.

Asesmen written feedback sebagai jenis asesmen dalam pembelajaran yang digunakan selama proses pembelajaran berangusng untuk memberikan feedback bagi siswa maupun guru, sehingga mereka bisa bertindak atas feedback yang didapatkan untuk meningkatkan proses belajar mengajar (Black, dkk., 2013). Dengan adanya feedback tersebut, tentunya dapat mendorong kemampuan belajar siswa sehingga dapat meningkatkan penguasaan konsep siswa dalam proses belajar.

Selain itu, Gioka (2010) menyatakan bahwa komentar dan feedback tertulis pada jawaban atau hasil pekerjaan siswa memiliki fungsi formatif spesifik yaitu untuk mendorong siswa berfikir tentang apa yang harus mereka ubah dan benarkan pada pekerjaan mereka.

Pembelajaran ekosistem memiliki peranan yang sangat penting dalam kehidupan sehari-hari. Pada pembelajaran ekosistem, hasil belajar yang seharusnya didapat oleh siswa sesuai dengan kompetensi dasar pada kurikulum 2013 yakni siswa mampu menganalisis informasi/data dari berbagai sumber tentang ekosistem dan semua interaksi yang berlangsung di dalamnya (Kemendikbud, 2013). Dengan demikian, siswa seharusnya dapat mengaplikasikan pemahaman terkait konsep ekosistem yang didapatkan pada pembelajaran kedalam kehidupan sehari-hari, misalnya terkait dengan menjaga komponen ekosistem agar berfungsi sesuai perannannya, serta melestarikan sumber daya alam agar interaksi dan aliran energi yang terjadi dalam ekosistem tetap seimbang.

Untuk memastikan bahwa siswa memiliki penguasaan konsep yang baik sebagai hasil belajar, dibutuhkan asesmen yang sesuai untuk meningkatkan penguasaan konsep siswa selama pembelajaran berlangsung. Wulan (2009) menyatakan bahwa dalam mengungkap penguasaan konsep siswa, asesmen tidakhanya mengungkap konsep yang 
telah dicapai, akan tetapi juga tentang proses perkembangan bagaimana suatu konsep tersebut diperoleh.

\section{METODE PENELITIAN}

Penelitian ini dilakukan pada bulan April 20182018 di SMP Negeri 6 Kota Sukabumi, yaitu pada siswa kelas VII G yang berjumlah 30 siswa.Metode yang digunakan pada penelitian ini adalah metode desktiptif, serta analisis data kuantitatif dan statistik.Data diambil dalam tiga kali pertemuan pembelajaran.

Peran asesmen written feedback terhadap penguasaan konsep siswa dijaring melalui tugas Lembar Kerja Siswa (LKS) yang dikumpulkan setelah pembelajaran. Guru memberikan written feedback pada LKS dan mengembalikan kepada siswa dua hari sebelum pembelajaran berikutnya. Peningkatan penguasaan konsep dilihat dari skor LKS yang dihasilkan oleh siswa. Adapun indikator peningkatan penguasaan konsep siswa adalah: penyusunan pertanyaan penelitian, langkah kerja, tabel pengamatan, menjawab pertanyaan dan menarik kesimpulan dari hasil pengamatan.

Pembelajaran berupa praktikum dilakuakan dalam tiga kali pertemuan.Pertemuan pertama praktikum tentang konsep ekosistem.Pertemuan kedua praktikum tentang interaksi makhuk hidup dan pertemuan ketiga praktikum tentang peristiwa makan dan dimakan atau jarring-jaring makanan.

Respon siswa terhadap penerapan asesmen written feedback dalam pembelajaran dilihat dari hasil analisis lembar angket yang diberikan kepada siswa.

\section{HASIL DAN PEMBAHASAN}

Berdasarkan observasi awal dilakukan sebelumnya, maka proses pengambilan data meliputi: 1) Pemilihan materi pembelajaran dan pembuatan perangkat pembelajaran. 2) Penyusunan instrumen penelitian berupa LKS dan angket. 3) Menyiapkan media serta alat dan bahan yang akan digunakan dalam pembelajaran. 4) Melaksanakan pembelajaran dan pengambilan data dalam tiga pertemuan. Pertemuan pertama mempelajari konsep lingkungan, pada pertemuan kedua mempelajari interaksi antar makhluk hidup dan pada 
pertemuan terakhir mempelajari rantai makanan, pada pertemuan ketiga juga siswa diberikan angket untuk menunjukkan respon siswa terhadap asesmen written feedback .

Beberapa indikator komentar yang digunakan dalam pembelajaran asesmen written feedback diantaranya; 1) Pada kolom pertanyaan penelitian dituliskan "sesuaikan pertanyaan penelitian dengan tujuan dan dasar teori yang ada”. 2) Pada kolom langkah kerja dituliskan "susunlah langkah kerja kebawah dan menggunakan kalimat aktif”. 3) Pada kolom pertanyaan dituliskan "jawablah pertanyaan sesuai dengan perintah yang ada dan jawab dengan sungguh-sungguh". 4) Pada kolom kesimpulan dituliskan "buatlah kesimpulan secara jelas dan rinci sesuai dengan pengamatan". Jika pada pertemuan selanjutnya siswa memperbaiki kesalahannya maka dituliskan "cukup baik", "baik”, dan "sangat baik" pada masing masing kolom komentar.

Tahap pelaksanaan pembelajaran atau tahap pengambilan data dilakukan dengan menggunakan metode Guided Inquiry dalam pembelajaran, dimana kelas dibagi menjadi 5 kelompok yang masing-masing terdiri dari 5 orang siswa. Pada tahap ini proses pengamatan dilakukan dengan bantuan observer. Observer yang membantu sebanyak dua orang. Hal ini dilakukan agar dalam mengamati kinerja siswa selama proses pembelajaran dapat teramati secara terperinci.

Berdasarkan hasil pelaksanaan pembelajaran pada pertemuan pertama yang dilaksanakan pada tanggal 2 April 2018 yang membahas konsep ekosistem, siswa diarahkan untuk dapat memahami LKS yang sudah disediakan oleh guru. Pembelajaran dilakukan di luar kelas dengan mengamati ekosistem sekitar sekolah. Pada pertemuan pertama ini siswa cukup antusias dalam melakukan pembelajaran, terlebih karena pembelajaran dilakukan di luar kelas sehingga siswa dapat aktif dan bebas melakukan pengamatan. Nilai LKS yang didapat siswa pada pertemuan pertama menunjukkan hasil yang cukup baik, hal ini dapat dilihat dari nilai rata-rata yang didapat oleh siswa sebesar 83.8. Selanjutnya dilakukan penilain dengan menggunakan asesmen written feedback, kemudian LKS dikembalikan pada tanggal 3April 2018.

Pertemuan kedua dilaksanakan pada tanggal 5 April 2018, materi yang dibahas adalah interaksi antar ekosistem, dimana siswa diminta untu mengamati ekosistem akuarium yang telah disediakan oleh guru. Pada pertemuan kedua diawali dengan memperbaiki kekurangan pada pertemuan pertama. Adapun beberapa poin yang 
ditekankan oleh guru unuk memperbaiki pembelajaran adalah sebagai berikut; 1) Guru lebih menekankan siswa untuk aktif dalam bertanya apabila ada materi yang belum dipahami. 2) Guru lebih menekankan kepada siswa agar lebih aktif dalam berdiskusi karena penilaian tidak hanya dilakukan pada akhir pembelajaran. 3) Guru menginformasikan poin penting terkait LKS yang akan dinilai, kesalahan yang terjadi pada pertemuan pertama, agar siswa lebih serius dan paham dalam mengisis LKS. Hasil nilai yang didapatkan pada pertemuan kedua mengalami peningkatan dari pertemuan pertama. Setelah dilakukan asesmen LKS dikembalikan kepada siswa pada tanggal 6 April 2018.

Pertemuan ketiga dilaksanakan pada tanggal 16 April 2018 yang membahas materi jarring-jaring makanan, diawali dengan memperbaiki kekurangan yang ada pada pertemuan kedua. Pada pertemuan ketiga siswa sudah mulai lebih baik dalam malaksanakan proses pembelajaran. siswa lebih serius dalam melakukan diskusi dan lebih teliti dalam mengisi LKS.Hasil nilai yang didapatkan pada pertemuan kedua mengalami peningkatan dari pertemuan pertama. Setelah dilakukan asesmen LKS dikembalikan kepada siswa pada tanggal 6 April 2018.

Pertemuan ketiga dilaksanakan pada tanggal 16 April 2018 yang membahas materi jarring-jaring makanan, diawali dengan memperbaiki kekurangan yang ada pada pertemuan kedua. Pada pertemuan ketiga siswa sudah mulai lebih baik dalam malaksanakan proses pembelajaran. siswa lebih serius dalam melakukan diskusi dan lebih teliti dalam mengisi LKS. Feedback yang dihasilkan dari asesmen written feedback mulai dapat dirasakan dilihat dari hasil nilai siswa yang semakin membaik. pada pertemuan ini siswa diberikan angket untuk mengetahui tanggapan siswa selama pembelajaran menggunakan asesmen written feedback. Berikut rerata peningkatan skor penguasaan konsep siswa dalam pembelajaran yang disajikan dalam diagram berikut: 


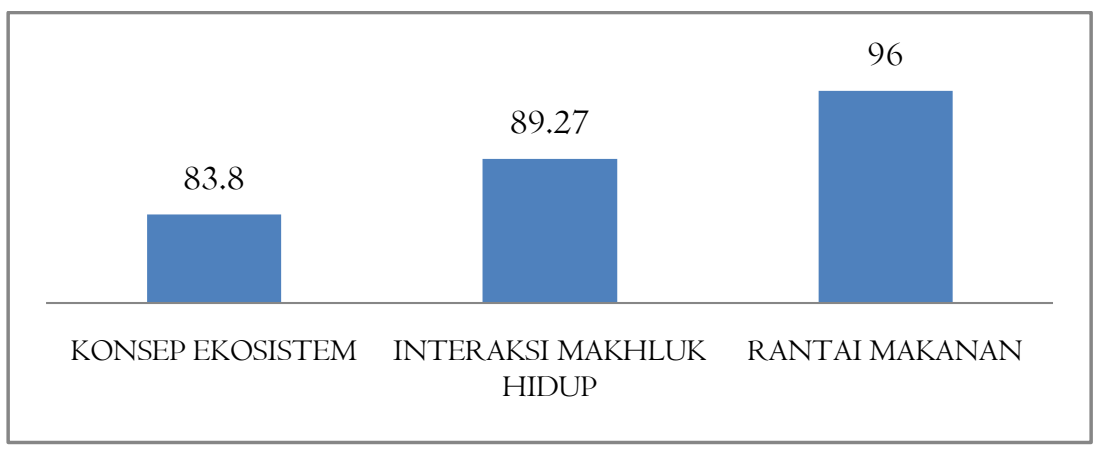

Gambar 1. Rerata Peningkatan Skor Penguasaan Konsep Siswa

Dari diagram diatas, terlihat bahwa terjadi peningkatan penguasaan konsep pada siswa setelah diberi asesmen written feedback. Secara umum dapat dilihat peningkatan penguasaan konsep siswa dimulai pada pertemuan kedua, dimana pada pertemuan pertama nilai rata-rata siswa sebesar 83.3, pada pertemuan kedua nilai rata-rata siswa meningkat menjadi 89.27 dan pada pertemuan ketiga nilai rata-rata siswa kembali meningkat menjadi 96. Akan tetapi walaupun peningkatanannya tidak terlalu tinggi, tetapi dengan pengujian statistic menunjukkan bahwa terjadi peningkatan dari penguasaan konsep siswa awal ke penguasaan konsep siswa akhir.Adapun persentase peningkatan penguasaan konsep siswa dapat dilihat dalam diagram berikut:

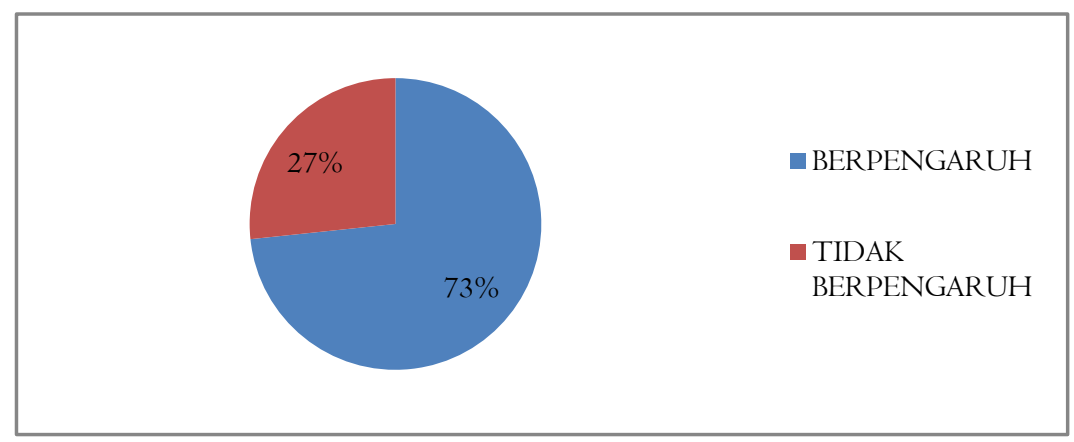

Gambar 2. Persentase Peningkatan Penguasaan Konsep Siswa

Dari diagram batang diatas, terlihat bahwa $73.33 \%$ siswa mengalami peningkatan penguasaan konsep setelah dilakukannya pembelajaran dengan asesmen written feedback , sedangkan $26.66 \%$ siswa tidak menunjukkan peningkatan. Siswa yang tidak menunjukkan peningkatan ini memiliki nilai yang lumayan baik dan stabil pada setiap pertemuannya sehingga tidak mengalami peningkatan, juga terdapat siswa yang mengalami penurunan nilai dalam pembelajaran. 
Berdasarkan observasi yang telah dilakukan, beberapa faktor yang menyebabkan penurunan nilai penguasan konsep siswa diantanya adalah kurangnya keseriusan siswa dalam melakukan pembelajaran, kurangnya minat siswa dalam belajar IPA, serta terdapat beberapa siswa yang menyatakan bahwa mereka tidak menyukai diberikan beban tugas individu oleh guru. Siswa yang memiliki kestabilan nilai merupakan siswa yang merasa acuh dengan penilaian komentar, mereka tidak menghiraukan adanya komentar pada LKS yang telah mereka buat sehingga tidak ada perubahan dari hasil yang mereka dapatkan. Respon siswa terhadap penerapan asesmen written feedback dalam pembelajaran dapat dilihat dalam diagram berikut:

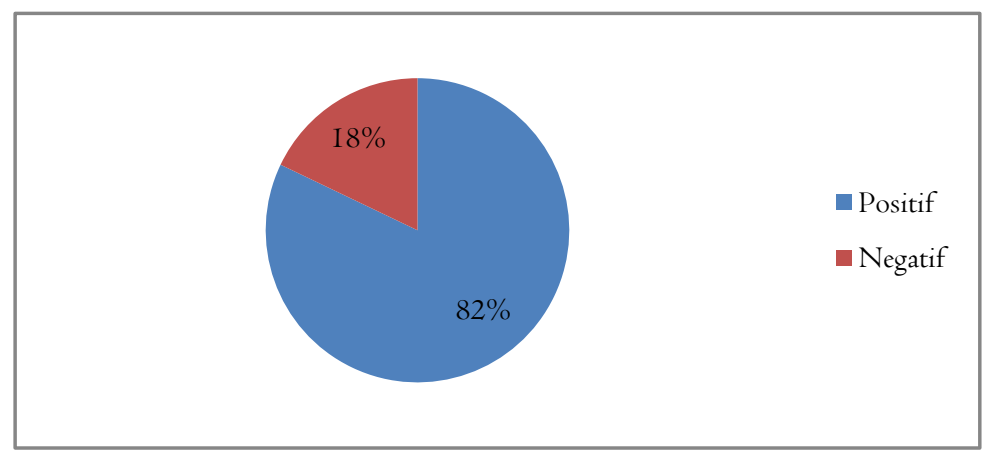

Gambar 3. Persentase Agket Respon Siswa

Berdasarkan diagram diatas terlihat bahwa, $82 \%$ siswa merespon positif terhadap pembelajaran menggunakan asesmen written feedback dan menyatakan adanya perubahan pola belajar pada dirinya. Sedangkan $18 \%$ siswa merespon negatif terhadap pembelajaran dengan menggunakan asesmen written feedback .Sebagian besar siswa yang merespon negatif adalah siswa yang kurang aktif dan tidak serius dalam belajar, sehingga mereka tidak merasakan ada perubahan yang terjadi pada pola belajar merka.

Asesmen written feedback merupakan salah satu asesmen yang dapat digunakan untuk melakukan penilaian selama proses pembelajaran. Beberapa karakteristik dari asesmen written feedback ini diantaranya dapat mengenali dan merespon belajar siswa dalam meningkatkan proses pembelajaran. Dengan demikian tentunya asesmen written feedback dapat memberikan feedback selama proses pembelajaran yang akan memantau dan mendorong peningatan penguasaan konsep siswa.

Peranan feedback dalam hal ini sangatlah perlu untuk mendukung kemampuan yang dilatihkan, oleh karena itu diperlukan feedback yang bersifat konstruktif 
(McCallum, B. 2000) karena feedback tersebut mengarahkan siswa pada jalur yang benar, meningkatkan hasil belajar yang kurang baik, memberi kesempatan kepada siswa untuk melakukan self assessment, menerapkan scaffolding, mengomentari kemajuan siswa dan memberi kesempatan pada siswa untuk memberikan respon terhadap feedback yang diberikan.

Penerapan asesmen formatif terutama feedback pada tugas-tugas siswa adalah sangat penting, karena informasi tentang kelemahan dan hasil serta proses belajar dengan segera bisa diketahui dan dengan segera pula dapat dilakukan perbaikan, penyesuaian dan perubahan strategi pada saat itu juga (Zainul, 2008).

Berdasarkan pada hasil penelitian dan hasil perhitungan dari setiap pertemuan yang telah dilakukan, didapatkan hasil yang menunjukkan bahwa setelah pembelajaran menggunakan asesmen written feedback, penguasaan konsep yang dimiliki siswa semakin meningkat setiap pertemuannya. Hal ini diketahui dari hasil skor LKS yang dikerjakan oleh siswa yang semakin meningkat disetiap pertemuannya.

Written feedback yang diberikan pada tugas LKS siswa dilaukan dengan cara memberi informasi berupa koreksi jawaban siswa yang salah atau kurang tepat. Terlihat dalamskor penguasaan konsep yang didapat siswa semakin meningkat setiap pertemuannya. Selama pembelajaran siswa dapat merasakan manfaat dari pemberian asesmen secara langsung karena pemberian asesmen fokus pada kesalahan yang dilakukan oleh siswa selama mengerjakan tugas. Hal tersebut ternyata berpengaruh untuk meningkatkan penguasaan konsep siswa menjadi lebih baik.

Siswa menerima feedback sebagai hal yang secara potensial menimbulkan motivasi, membantu meningkatkan keinginan untuk belajar dan meningkatkan kemampuan kognitif yakni penguasaan konsep siswa untuk menyelesaikan tugas LKS yang diberikan, membantu memahami fenomena sekitar tentang ekosistem dan lingkungan, dan secara jelas mengetahui pencapaian dan kemajuan belajarnya. Agar feedback yang diberikan bermanfaat bagi siswa, seorang guru harus melakukannya secara terencana, konstruktif dan berkelanjutan. Guru harus menjelaskan tentang feedback apa yang ingin diberikan. Siswa perlu mengetahui apakah mereka telah mengerjakan tugas dengan baik dan benar. 
Penggunaan asesmen written feedback dalam pembelajaran juga melatih siswa untuk mengetahui keslaahan dari korekssi yang diberikan oleh guru yang membuat pikiran siswa menjadi terbuka. Sehingga siswa tersebut tidak akan melakukan keslahan yang sama dan mengerti bagaimana jawaban yang seharusnya. Pemberian asesmen written feedback ini juga dapat membantu siswa untuk mengatasi kesulitan dalam menjawab soal dan membuat siswa dapat meningkatkan hasil belajar mereka. Hal ini sesuai dengan pendapat Suke Silverius (dalam Lathifatul, 2008) bahwa feedback adalah pemberian informasi yang diperoleh dari tes atau alat ukur lainnya kepada siswa untuk memperbaiki atau meningkatkan pencapaian hasil belajar. Namun dalam penelitian ini masih terdapat kekurangan yakni waktu pelaksanaan penelitian ini masih kurang sehingga hasil yang diperoleh masih belum stabil.

Penelitian yang dilakukan oleh beberapa peneliti (Gunn \& Pitt, 2003; Alasdair 2006; Baggot \& Rayne, 2007 dan Ziman et al., 2007) menunjukkan hasil bahwa pemberian asesmen dan feedback secara umum dapat memotivasi belajar siswa, mendorong siswa untuk tertarik pada topik yang diajarkan, meningkatkan hasil belajar dan menimbulkan optimisme, kepercayaan diri dan apresiasi siswa. Mencermati dampak positif dari penerapan asesmen. maka pada penelitian ini diterapkan berbagai strategi asesmen formatif.

Hasil penelitian lain yang dilakukan oleh Granbom (2014) menyatakan bahwa asesmen written feedback membuat siswa memiliki kinerja yang lebih baik dan hasil belajar yang lebih tinggi. Dengan asesmen written feedback, siswa mendapat feedback dari guru dan saling memberi feedback sesama siswa, selain itu siswa juga mendapat banyak kesempatan untuk merefleksi dan mengevaluasi pemahaman mereka tentang suatu topik. Hal ini juga diduga menjadi faktor penting yang memperbaiki pembelajaran.

Asesmen written feedback sebagai jenis asesmen dalam pembelajaran yang digunakan selama proses pembelajaran berangusng untuk memberikan feedback bagi siswa maupun guru, sehingga mereka bisa bertindak atas feedback yang didapatkan untuk meningkatkan proses belajar mengajar (Black, dkk., dalam Yin, 2013). Dengan adanya feedback tersebut, tentunya dapat mendorong kemampuan belajar siswa sehingga dapat meningkatkan penguasaan konsep siswa dalam proses belajar. Selain itu, Gioka (2010) menyatakan bahwa komentar dan feedback tertulis pada jawaban atau hasil pekerjaan 
siswa memiliki fungsi formatif spesifik yaitu untuk mendorong siswa berpikir tentang apa yang harus mereka ubah dan benarkan pada pekerjaan mereka.

Pada pertemuan ketiga, siswa diminta untuk mengisi angket respon siswa terhadap pembelajaran menggunakan asesmen written feedback untuk mengetahui bagaimana pendapat siswa mengenai pembelajaran menggunakan asesmen written feedback.

Berdasarkan hasil pengolahan data mengenai angket respon siswa terhadap penerapan asesmen written feedback pada pembelajaran materi ekosistem, hasil menunjukkan respon yang positif dari siswa terhadap penerapan asesmen written feedback pada pembelajaran materi ekosistem. Dari angket tersebut siswa menyatakan bahwa pembelajaran menggunakan asesmen written feedback sangat menarik bagi mereka juga meningkatkan minat dalam pembelajaran IPA disekolah. Siswa merasa mereka jadi ngetahu kekurangan yang mereka miliki selama pemelajaran dan memperbaiki kekurangan tersebut secara bertahap.

Respon positif terhadap pengalaman belajar menggunakan asesmen written feedback dapat terlihat pada beberapa indikator yang ada pada angket. Hal ini dapat diketahui bahwa selama diterapkannya asesmen written feedback siswa menjadi lebih rajin, lebih aktif dan belajar dengan sungguh-sungguh. Siswa juga menjadi mempunyai motivasi yang tinggi untuk mendapatakan nilai tinggi.

Berdasarkan beberapa pendapat dan hasil penelitian yang telah dilakukan, menunjukkan bahwa analisis penguasaan konsep siswa melalui penerapan asesmen written feedback dapat mendorong siswa untuk lebih aktif dalam proses pembelajarannya, membangun motivasi siswa untuk mau berproses dan meningkatkan kemampuan yang mereka miliki. Dengan kata lain penerapan asesmen written feedback sangat layak untuk diterapkan dalam pembelajaran disekolah.

Sependapat dengan itu Orsmond et al. (2005) dalam Milton (2005) menyatakan bahwa feedback juga membantu siswa untuk belajar khususnya memperhatikan pada siswa tentang kekuatan dan kelemahan pekerjaannya. Siswa mengenal feedback sebagai hal yang secara potensial menimbulkan motivasi, membantu mereka meningkatkan belajar dan meningkatkan kemampuannya dalam mengerjakan tugas-tugas, membantu mereka lebih reflektif (melakukan self assessment) dan secara jelas mengetahui pencapaian dan kemajuan belajarnya. 


\section{SIMPULAN}

Dari penelitian ini dapat disimpulkan bahwa pemberian asesmen written feedback dalam pembelajaran dapat meningkatkan penguasaan konsep siswa. Penerapan asesmen written feedback juga dapat mendorong siswa untuk lebih aktif dalam proses pembelajarannya, membangun motivasi siswa untuk mau berproses dan meningkatkan kemampuan yang mereka miliki. Dengan kata lain penerapan asesmen written feedback sangat layak untuk diterapkan dalam pembelajaran disekolah.

\section{DAFTAR PUSTAKA}

Alasdair, G.T. (2006). Using Online Microassessment to Drive Student Learning.Bioscience Education e-Journal. 2006.

Black, P. \& William, D. (1998).Assessment and Classroom Learning.Assessment in Education.

Black, P. and William, D. (1998).Inside The BlackBox: Raising Standard Through Classroom Assessment. Phi Delta Kappan.

Gioka, Olga. (2010). Assessment for Learning in Biology Lessons.Journal of Biological Education.

Gunn, A and Pitt, S.J. (2003).The effectiveness of computer-based teaching packages in supporting student learning of Parasitology..Bioscienc eEducation e-Journal. 2003.

Hart, D. (1994). Authentic Assessment: A Handbook for Educator. California: Addison-Wesley Publishing Company.

Kemendikbud.(2013). Kerangka Dasar dan Struktur Kurikulum Sekolah Menengah Atas/Madrasah Aliyah. Jakarta: Menteri Pendidikan dan Kebudayaan.

Mc Callum. (2000). Formative assessment: implications for classroom practice. Whole-school development in assessment for learning: Crown. www.publication.education.gov.uk/default

Milton, J. (2005). Exploration of The Nature of Feedback to Students. EAC: Learning and Teaching Development. RMIT University.(Online).

Uno, Hamzah B. (2011). Model Pembelajaran Menciptakan Proses Belajar Mengajar yang Kreatif dan Efektif. Jakarta: Bumi Aksara.

Wulan, A.R. (2009). Strategi Asesmen Portofolio pada Pembelajaran Biologi di SMA. Dapat diunduh dari http://file.upi.edu/Direktori/SPS/PRODI.PENDIDIKAN_IPA/197404 171999032-ANA_RATNAWULAN/ASESMEN_PORTOFOLIO.pdf. 
Yin, Y. dkk. (2013). Using Formal Embedded Formative Assessments Aligned with a Short-Term Learning Progression to Promote Conceptual Change and Achievement in Science.

Zainul, A. (2008). Asesmen Sumatif dan Asesmen Formatif.Bahan Kuliah Evaluasi Pendidikan IPA di Prodi Pendidikan IPA Pascasarjana UPI.

Ziman, M. et al. (2007).Student optimism and appreciation of feedback.Teaching and Learning Forum 2007. 